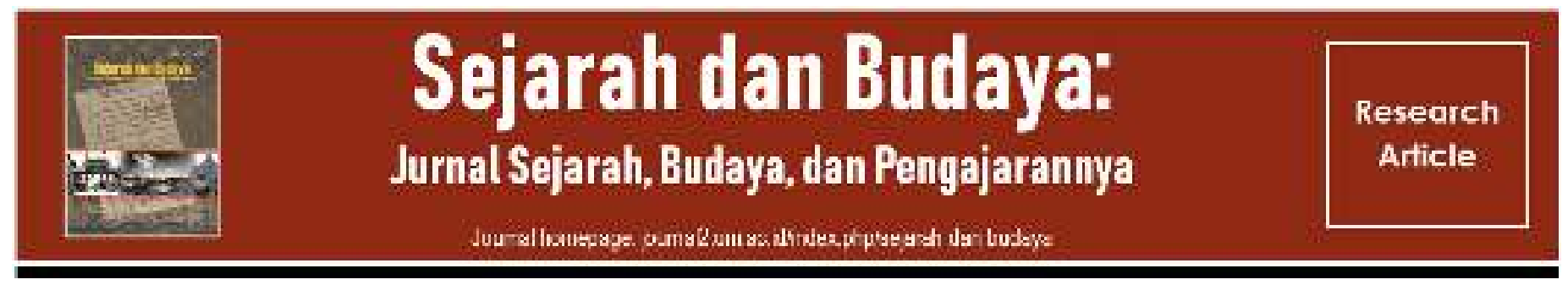

\title{
KEHIDUPAN SOSIAL BUDAYA MASYARAKAT KETURUNAN ARAB DAN PENDUDUK LOKAL DESA PULOPANCIKAN GRESIK
}

\author{
Elsa Diah Mafazaha, Neni Wahyuningtyas ${ }^{b}$ \& I Nyoman Rujac \\ elsadiahmafazah95@gmail.com
}

aUniversitas Negeri Malang, Indonesia.

bUniversitas Negeri Malang, Indonesia.

cUniversitas Negeri Malang, Indonesia.

\section{ARTICLE INFO}

Received: 3 March 2020

Revised: 30 June 2020

Accepted: 30 June 2020

Published: 30 June 2020

\section{Permalink/DOI}

$\overline{10.17977 / u m 020 v 14 \mathrm{i} 12020 \mathrm{p} 105}$

Copyright (C) 2019, Sejarah dan

Budaya. All right reserved

Print ISSN: $1979-9993$

Online ISSN: 2503-1147

\begin{abstract}
Social interaction is very necessary in human life, especially in the process of social relations. Social relations in society can create a form of interaction in social groups. This study uses a qualitative approach to the type of descriptive research. This research was conducted in Pulopancikan Village, Gresik Regency. Data obtained from primary data and secondary data. The data collection techniques in this study are observation, interviews, and documentation. Based on these studies it can be concluded that the beginning of the existence of Kampung Arab, Pulopancikan Village, Gresik Regency, originated from the arrival of the Hadramaut Arabs around the 19th century who carried out trading activities and also preached to spread the teachings of Islam.
\end{abstract}

\section{KEYWORDS}

History of Arab Village, Cultural Characteristics, Social Interaction.

\begin{abstract}
ABSTRAK
Interaksi sosial sangat diperlukan dalam kehidupan manusia, terutama dalam proses untuk melakukan hubungan sosial. Hubungan sosial dalam masyarakat dapat menciptakan suatu bentuk interaksi dalam kelompok sosial. Penelitian ini menggunakan pendekatan kualitatif dengan jenis penelitian deskriptif. Penelitian ini dilakukan di Desa Pulopancikan Kabupaten Gresik. Data diperoleh dari data primer dan data sekunder. Adapun teknik pengumpulan data dalam penelitian ini yakni observasi, wawancara, dan dokumentasi. Berdasarkan penelitian tersebut dapat disimpulkan bahwa awal mula keberadaan Kampung Arab Desa Pulopancikan Kabupaten Gresik berasal dari datangnya bangsa Arab Hadramaut pada sekitar abad ke-19 yang melakukan kegiatan berdagang dan juga berdakwah untuk menyebarkan ajaran agama Islam.
\end{abstract}

KATA KUNCI

Sejarah Kampung Arab, Karakteristik Budaya, Interaksi Sosial.

\section{PENDAHULUAN}

Manusia merupakan makhluk sosial yang tidak mampu hidup sendiri di dunia baik dalam konteks fisik maupun sosial budaya (Burhan 2006). Interaksi sosial sangat diperlukan dalam kehidupan manusia, terutama dalam proses untuk melakukan hubungan sosial. Seperti halnya yang terjadi pada Negara Indonesia yang notabene sebagai negara majemuk, Indonesia memiliki beragam etnis dan budaya. Keragaman etnis yang dimiliki Indonesia memunculkan interaksi sosial antar etnis. Budaya yang dilakukan masyarakat Kampung Arab di Desa Pulopancikan Kabupaten Gresik dapat 
menciptakan interaksi masyarakat. Interaksi tersebut tidak hanya dilakukan pada saat melakukan tradisi budaya saja, akan tetapi juga dalam kegiatan sehari-hari. Desa Pulopancikan Kabupaten Gresik tidak hanya terdiri dari masyarakat keturunan Arab yang tinggal di Kampung Arab, akan tetapi terdapat juga penduduk lokal daerah tersebut. Sehingga proses interaksi yang terjadi tidak hanya antar masyarakat keturunan Arab yang berada di Kampung Arab, akan tetapi juga antara masyarakat Kampung Arab dengan penduduk lokal Desa Pulopancikan Kabupaten Gresik.

Interaksi sosial masyarakat keturunan Arab dengan penduduk lokal yang ada di Desa Pulopancikan Kabupaten Gresik menarik untuk diteliti karena melihat realitas sosial bahwa terdapat dua etnis yang berbeda dalam satu kompleks wilayah, yakni etnis Arab pada masyarakat keturunan Arab dan penduduk lokal yang merupakan etnis Jawa, sehingga peneliti ingin mengungkap alasan bagaimana interaksi sosial antar etnis tersebut. Peneliti melakukan penelitian tentang interaksi sosial masyarakat Kampung Arab dengan penduduk lokal di Desa Pulopancikan Kabupaten Gresik karena Desa Pulopancikan memiliki keistimewaan. Desa Pulopancikan merupakan wilayah Sunan Malik Ibrahim yakni salah satu dari wali songo untuk menyebarkan agama Islam serta Desa Pulopancikan merupakan salah satu desa yang memiliki Kampung Arab tertua di Kabupaten Gresik.

Penelitian ini difokuskan dengan bagaimana sejarah Kampung Arab di Desa Pulopancikan Kabupaten Gresik, bagaimana karakteristik budaya masyarakat Kampung Arab di Desa Pulopancikan Kabupaten Gresik serta bagaimana interaksi sosial masyarakat Kampung Arab di Desa Pulopancikan Kabupaten Gresik. Selanjutnya peneliti menggunakan kajian pustaka tentang interaksi sosial yang digunakan sebagai acuan dalam membahas hasil temuan di lapangan. Berdasarkan latar belakang tersebut penulis tertarik untuk melakukan penelitian yang berjudul "Interaksi sosial masyarakat Kampung Arab dengan penduduk lokal Desa Pulopancikan Kabupaten Gresik".

\section{METODE}

Penelitian ini menggunakan pendekatan penelitian kualitatif dengan jenis penelitian deskriptif. Menurut Sukmadinata (2016), penelitian deskriptif kualitatif ditujukan untuk mendeskripsikan dan menggambarkan fenomena yang ada, baik bersifat alamiah maupun rekayasa manusia, yang lebih memperhatikan mengenai karakteristik, kualitas, dan keterkaitan antar kegiatan. Lokasi yang dijadikan objek penelitian ini adalah Kampung Arab Desa Pulopancikan Kecamatan Gresik Kabupaten Gresik. Sumber data dalam penelitian ini terdiri atas data primer dan data sekunder. Penelitian ini menggunakan teknik pengumpulan data berupa observasi, wawancara, dan dokumentasi. Wawancara dilakukan dengan informan kunci dan juga informan pendukung. Informan kunci dalam penelitian ini terdiri dari FM, ST, AM, ZN, ND, MY, KD, ZZ, ND, dan TR. Sedangkan informan pendukung dalam penelitian ini adalah AA selaku Kepala Desa Pulopancikan Kabupaten Gresik. Teknik analisis data yang digunakan dalam penelitian ini adalah model interaktif Miles dan Huberman, yang terdiri dari pengumpulan data, reduksi data, penyajian data, dan penarikan kesimpulan. 


\section{HASIL DAN PEMBAHASAN}

\section{Sejarah Kampung Arab Desa Pulopancikan Kabupaten Gresik}

Awal mula kedatangan bangsa Arab ke Indonesia berasal dari datangnya bangsa Arab Hadramaut pada sekitar abad ke-12 (Saidah 2015). Orang-orang dari Hadramaut dikenal sebagai pedagang dan pelaut sehingga mereka disebut dengan orang Phoenicia dari Timur Tengah (Pusat et al., n.d.). Migrasi orang-orang dari Hadramaut ke Indonesia disebabkan oleh beberapa faktor yakni kesulitan perekonomian yang terjadi di Hadramaut, mudahnya sarana transportasi terutama dalam hal pelayaran, dan kebijakan ekonomi pemerintah Belanda yang menjadikan kaum minoritas Arab dan Cina sebagai perantara perdagangan internasional (Mahzumi 2014). Selain itu, orangorang dari Hadramaut yang merupakan negeri miskin melakukan kegiatan berdagang dan juga berdakwah untuk menyebarkan ajaran agama Islam (Yunita 2017).

Kedatangan bangsa Arab ke Indonesia merupakan efek samping dari ramainya jalur pelayaran dan juga aktifitas perdagangan dunia antara Asia Barat Daya, Asia Selatan dan Asia Timur Raya. Perdagangan melalui jalur laut pada masa itu sangat bergantung pada angin musim utara untuk ke selatan. Pada saat perubahan musim atau timbul badai, para pedagang untuk sementara menetap di pelabuhan-pelabuhan Asia Tenggara karena alasan perdagangan yakni menunggu rekan dagang dari Negara lainnya untuk menukar barang sehingga para pedagang tersebut menetap di kota yang disinggahinya. Di Pulau Jawa, beberapa kota yang biasa disinggahi dan disebut sebagai kota pelabuhan serta pusat tukar-menukar barang adalah Sunda Kelapa, Banten, Cirebon, Semarang, Lasem, Jepara, Demak, Tuban, Surabaya, dan Gresik (Handinoto 1999).

Pada paruh ke-2 abad ke 14 didirikanlah pelabuhan Gresik oleh kerajaan Majapahit dan juga bersamaan dengan datangnya Syekh Maulana Malik Ibrahim beserta 40 orang rombongannya (Saidah 2015). Pada saat itu, Raja Majapahit menghadiahkan kepada Syekh Malik Ibrahim tanah di Gapurosukolilo dan juga menjadi syahbandar karena telah menarik simpati Raja Majapahit. Setelah itu, Syekh Malik Ibrahim pindah ke wilayah tersebut dan menyebarkan agama Islam. Lambat laun, wilayah tersebut semakin padat dengan berdirinya permukiman para pengikutnya dan beberapa santri datang untuk berguru kepada beliau. Namun keberadaan Kampung Arab ini tidak hanya karena adanya Syekh Malik Ibrahim saja, akan tetapi juga karena Gresik sebagai kota pelabuhan sekaligus jalur lalu lintas pelayaran yang menyebabkan banyaknya orang asing seperti pedagang dari Arab yang menetap sementara maupun selamanya. Hal tersebut menjadikan wilayah yang didatangi oleh pedagang maupun pendakwah menjadi sebuah permukiman yang disebut dengan Kampung Arab.

Kampung Arab Pulopancikan merupakan pemukiman pedagang Arab yang berada di wilayah Gresik. Pulopancikan berasal dari kata "pulo" yang artinya daratan, dan "pancikan" yang artinya pijakan. Arti dari nama wilayah tersebut sesuai dengan peristiwa awal kedatangan para pedagang Arab Hadramaut melalui pelabuhan Gresik yang menjadikan Pulopancikan sebagai tempat pijakan awal untuk mencari tempat 
bermukim. Sehingga, Kampung Arab di Pulopancikan merupakan Kampung Arab tertua di Gresik (Wiretno 2018).

Pada tahun 1830-1890 merupakan masa kejayaan komunitas masyarakat keturunan Arab dengan kepemimpinan Syekh Said bin Salim Naum dan Said Ali bin Achmad bin Sahabiedin Segaf. Pada masa tersebut perkembangan kemajuan jumlah komunitas Arab dipengaruhi oleh adanya peraturan Undang-Undang Wijkenstensel di Pulau Jawa yang dikeluarkan oleh pemerintah Hindia-Belanda pada tahun 1826. Peraturan tersebut berbunyi “orang-orang Timur asing yang menjadi penduduk HindiaBelanda dikumpulkan pada daerah terpisah dipimpin oleh kepala pimpinan masingmasing" (Saidah 2015). Peraturan tersebut menjelaskan bahwa etnis-etnis yang berada di wilayah pemerintahan Hindia-Belanda harus pindah sesuai dengan wilayah yang telah ditentukan oleh pemerintah Hindia-Belanda. Akibat dari peraturan Wijkenstensel, maka orang-orang Arab pada wilayahnya sendiri semakin memperkuat hubungan dalam komunitasnya. Selain itu, fakta mengenai banyaknya pengunjung dari Arab yang datang ke Pelabuhan Gresik karena Gresik merupakan daerah pantai yang pelabuhannya terbuka bagi siapapun pengunjungnya (Zainuddin 2010). Menurut Hilmiyyah (2019) banyaknya pengunjung yang datang ke pelabuhan Gresik juga dikarenakan pelabuhan Gresik yang berada diantara selat Madura dan dibelakangi oleh delta bengawan solo sehingga dianggap sebagai pelabuhan yang aman karena terlindung dari ombak besar dan arus yang kuat serta angin yang besar.

Jumlah komunitas Arab di Gresik pada tahun 1890-1930 mengalami kemunduran yakni pada saat dibangunnya pelabuhan Tanjung Perak Surabaya pada tahun 1911. Dengan dibangunnya pelabuhan tersebut, maka aktivitas perdagangan di pelabuhan Gresik banyak yang pindah ke pelabuhan Tanjung Perak karena pelabuhan Tanjung Perak dilengkapi dengan fasilitas yang lebih canggih sehingga memudahkan pengangkutan barang dagangan. Selain itu, kemunduran jumlah komunitas Arab di Gresik juga dikarenakan pada tahun 1920 pemerintah kolonial Belanda menghapus peraturan Wijkenstensel karena banyaknya protes dari luar negeri tentang diskriminasi pemerintah kolonial Belanda terhadap orang timur asing yakni penempatan wilayah di kota yang tidak sehat (Saidah 2015). Hal tersebut menjadikan orang-orang Arab yang berada di Kampung Arab Gresik memilih untuk pindah dan meninggalkan wilayah Gresik untuk mencari tempat yang lebih sehat dan memulai usaha baru. Meskipun demikian, masih ada beberapa anggota komunitas Arab yang masih bertahan di Gresik terutama di Desa Pulopancikan. Hal tersebut dikarenakan beberapa anggota komunitas Arab yang telah membuka usaha perdagangan dan memiliki tanah di Gresik. Selain itu, terdapat juga beberapa komunitas Arab yang telah menikah dengan penduduk lokal Desa Pulopancikan Kabupaten Gresik.

\section{Karakteristik Budaya Masyarakat Kampung Arab Desa Pulopancikan Kabupaten Gresik}

Masyarakat keturunan Arab di Kampung Arab Desa Pulopancikan Kabupaten Gresik mempunyai karakteristik budaya yang khas dimana masih terdapat budaya- 
budaya Arab meskipun telah terdapat akulturasi dengan budaya Jawa. Beragam tradisi budaya merupakan salah satu hal yang sangat bernilai (Bisyarda 2016). Masyarakat keturunan Arab menghormati tradisi yang bertujuan untuk melestarikan kebiasaan masa lalu serta sistem kepercayaan mereka (Ajami 2016). Karakteristik budaya masyarakat Kampung Arab di Desa Pulopancikan Kabupaten Gresik ini peneliti jabarkan berdasarkan 7 unsur kebudayaan universal yang ada:

\section{A. Bahasa}

Bahasa sehari-hari yang digunakan masyarakat keturunan Arab adalah bahasa Indonesia dan jawa, akan tetapi bahasa Arab digunakan pada kegiatan tertentu. Selain itu, bahasa Arab juga digunakan oleh masyarakat keturunan Arab tertentu seperti para kyai pada kegiatan tertentu seperti kegiatan rutinan yaitu rawhah dan ta'lim yang diselenggarakan oleh masyarakat keturunan Arab setempat. Bahasa Arab juga digunakan di lembaga TPQ maupun sekolah yang berbasis Islam, akan tetapi tidak untuk bahasa sehari-hari.

\section{B. Sistem Pengetahuan}

Sistem pengetahuan yang didapat masyarakat Kampung Arab Desa Pulopancikan Kabupaten Gresik berasal dari keluarga dan juga lembaga pendidikan. Salah satu lembaga pendidikan yang terdapat di Kampung Arab Desa Pulopancikan adalah Muhajirin Center, dimana lembaga tersebut merupakan lembaga pendidikan dan dakwah yang terdiri dari beberapa kelompok kegiatan. Pertama, Kelompok Bermain dan Taman Kanak-Kanak (KBTK) hafiz Quran Al-Muhajirin yang terdiri dari anak usia 24 tahun untuk kelompok bermain dan anak usia 4-6 tahun untuk kelompok taman kanak-kanak. Dengan memiliki visi cerdas, kreatif, dan cinta Al-Quran, tujuan utama dalam KBTK hafizh Quran Al-Muhajirin adalah anak dapat menghafalkan Al-Quran juz 29 dan 30. Kedua, Sekolah Hafiz Quran (SHQ) yang terdiri dari anak usia 3-18 tahun. SHQ merupakan salah satu kelompok cabang dari lembaga Muhajirin Center yang memiliki prinsip "One Family One Hafizh Quran" dimana lembaga tersebut diharapkan mampu melahirkan minimal satu orang hafiz Quran dalam satu keluarga. Ketiga, Taman Pendidikan Al-Quran (TPQ) Al-Muhajirin yang merupakan salah satu sekolah keagamaan yang memiliki tujuan untuk menjadikan santri sebagai lulusan yang mampu membaca Al-Quran dengan tartil, memahami dasar ilmu tajwid, hafal surat-surat pendek dan ayat Al-Quran pilihan, mampu menulis huruf Al-Quran, cakap dalam ubudiyah sehari-hari, hafal doa harian dan asmaul husna, serta memahami dasar-dasar agama Islam.

Masyarakat dari keturunan Arab memprioritaskan anaknya untuk sekolah di pondok pesantren. Akan tetapi, terdapat banyak juga anak-anak dari masyarakat keturunan Arab yang sekolah di lembaga pendidikan formal yang negeri. Selain itu, terdapat stigma di masyarakat keturunan Arab bahwa perempuan keturunan Arab yang berada di Kampung Arab Desa Pulopancikan tidak perlu melanjutkan sekolah ke jenjang yang tinggi karena sistem perjodohan antar masyarakatnya sangat kental. Akan tetapi, pada saat ini terdapat beberapa perempuan keturunan Arab yang sudah melanjutkan pendidikan ke jenjang tinggi. 


\section{Organisasi Sosial}

Organisasi sosial dalam masyarakat Kampung Arab sering dikaitkan dengan sistem kekerabatan antar keturunan yang disebut dengan fam. Masyarakat Kampung Arab memiliki nasab yang menjadi nama marga dalam keturunannya. Saidah (2015) menjelaskan bahwa marga yang dimiliki oleh masyarakat keturunan Arab berasal dari orang Arab Hadramaut yang datang ke Indonesia, diantaranya adalah:

1. Golongan Saada atau Baalwinatau alawy atau golongan habaib, yakni golongan tertinggi dan terpandang. Nama famnya adalah Alatas, Al-Hadda, Al-Gadri, Bafagih, Assegaf, Al-Mahdali, dan Al-Habsyi.

2. Golongan Qaabail yakni golongan ningrat duniawi. Nama famnya adalah $A l-$ Laktiri, Bin Thalib, Bin Mahri, dan Al-Makarim.

3. Golongan Masyaayikh, yakni orang-orang yang bergerak dalam bidang pendidikan dan pengajaran. Nama famnya adalah Al-Bafadhal, Al-Bawazir, AlMudi, Al-Iskak, Al-Bajabir, Al-Skahak, Bin Afif, Al-Baqis, Al-Barras.

4. Golongan $D a$ 'fa dan Masakin, yakni golongan yang terdiri dari petani, pedagang, pengrajin,. Fam mereka adalah Audah, Bama, Symus, Faqih, Makki, Baswedan, Argubi.

5. Golongan $A^{\prime}$ bid, yakni golongan budak.

Sistem kekerabatan masyarakat keturunan Arab tidak hanya diwujudkan dalam nama marga saja, akan tetapi juga terwujud dalam wadah sosial yayasan "Muhajirin Center" yang berlokasi di Jalan KH. Zubair No.54. Kegiatan sosial yang pernah diadakan adalah khitan massal untuk 100 peserta anak usia 8 bulan sampai 13 tahun. Kegiatan sosial lain yang diadakan adalah pemberian bantuan kepada masyarakat yang kurang mampu dalam hal untuk memenuhi kebutuhan hidup sampai pembangunan rumah.

Selain itu, kekerabatan dalam hal pernikahan juga memiliki keunikan yakni melakukan perjodohan dengan sesama etnis Arab yang dilakukan untuk mempertahankan marga atau fam yang dimiliki. Masyarakat keturunan Arab sangat memegang teguh sistem sosial yang selama ini diyakini yaitu patriarki, dimana sistem ini menjadikan laki-laki sebagai penentu kekuasaan dan memiliki hak istimewa dalam berbagai kepentingan terhadap perempuan, anak-anak, dan benda (Shelvira 2019). Laki-laki dipercaya untuk menjadi pemimpin karena dapat bertanggungjawab membimbing anggotanya keluarganya (Suhandjati 2018). Poespasari (Poespasari and SH 2016) menjelaskan bahwa keluarga keturunan Arab mengikuti nasab garis keturunan laki-laki atau garis keturunan ayah. Sistem kekerabatan yang patrilineal tersebut mempunyai makna agar garis keturunan Arab yang dimiliki tidak hilang.

Sistem pernikahan patrilineal mengatur masyarakat keturunan Arab perempuan diharuskan untuk menikah dengan laki-laki keturunan Arab juga. Akan tetapi, untuk laki-laki keturunan Arab boleh menikahi perempuan dari bukan keturunan Arab. Selain itu, dalam melakukan perjodohan masyarakat keturunan Arab harus mempertimbangkan strata atau fam yang setara. Perempuan dari golongan alawiyin hanya dapat dinikahi oleh golongan alawiyin juga. Untuk perempuan dari golongan irsyaddin diperbolehkan untuk dinikahi oleh laki-laki dari golongan yang lebih tinggi 
atau sama (Shelvira 2019). Perempuan dari kedua golongan tersebut tidak diperbolehkan untuk menikah dengan laki-laki non Arab karena dianggap memutuskan garis keturunan Nabi oleh masyarakat keturunan Arab. Apabila terdapat masyarakat yang melanggar hal tersebut, maka akan dikucilkan dari keluarga bahkan sudah dianggap keluar dari fam keluarga tersebut.

\section{Sistem Peralatan Hidup dan Teknologi}

Sistem peralatan hidup dan teknologi merupakan wujud fisik budaya yang digunakan oleh manusia dalam kehidupan sehari-hari (Koentjaraningrat 2009). Sistem peralatan hidup dan teknologi masyarakat keturunan Arab hampir sama dengan masyarakat Jawa pada umumnya. Terdapat keunikan yang dimiliki masyarakat keturunan Arab seperti adanya alat khas timur tengah yakni shisha yakni alat untuk merokok. Namun shisha sudah jarang sekali digunakan dalam kehidupan sehari-hari oleh masyarakat keturunan Arab di Kampung Arab Desa Pulopancikan Kabupaten Gresik. Wujud fisik budaya lain sebagai ciri masyarakat keturunan Arab yakni cara berpakaian masyarakat keturunan Arab yang menggaambarkan identitas Arab seperti berpakaian jubah, memakai niqab (cadar), dan memakai sorban.

\section{E. Sistem Mata Pencaharian Hidup}

Mata pencaharian masyarakat keturunan Arab di Kampung Arab Desa Pulopancikan bergerak dalam perdagangan yakni produksi sarung sebagai komoditas utamanya. Terdapat pula produksi taqwa (busana muslim laki-laki), kopyah, parfum, dan makanan khas timur tengah seperti roti canai atau roti maryam. Dalam produksi sarung, kebanyakan pemilik pabrik sarung adalah masyarakat dari keturunan Arab sedangkan para pekerjanya merupakan penduduk lokal sekitar. Penggunaan handphone lebih disukai untuk berdagang oleh masyarakat Kampung Arab karena dapat berdagang dengan tidak langsung menemui pembelinya.

\section{F. Agama}

Masyarakat Kampung Arab di Desa Pulopancikan menganut agama Islam dengan berbagai aliran-aliran tertentu seperti NU dan Muhammadiyah. Kegiatan keagamaan yang ada di Kampung Arab Desa Pulopancikan antara lain rawhah, ta'lim, dan halaqoh yang merupakan kegiatan rutin yang bertempat di kediaman Habib Abu Bakar jalan KH. Zubair. Kegiatan rawhah merupakan salah satu kegiatan yang dipimpin oleh habib dan dilaksanakan khusus orang laki-laki pada waktu pagi dengan membaca kitab ihya' Ulumuddin yakni kitab yang berisi tentang prinsip dalam menyucikan jiwa atau cara dalam mengobati penyakit hati. Sedangkan kegiatan ta'lim dilakukan pada hari minggu dengan membaca kitab risalatul jamiah yaitu kitab yang membahas ttentang ilmu agama Ialam dan bidayatul hidayah yakni kitab yang membahas tentang proses awal manusia dalam mendapatkan hidayah dari Tuhan. Untuk kegiatan Halaqoh, hampir sama seperti majlis ta'lim yang dihadiri oleh remaja perempuan pada hari minggu.

Terdapat juga houl Habib Abu Bakar bin Muhammad Assegaf yang merupakan sosok ulama yang disegani oleh masyarakat. Houl tersebut adalah kegiatan tahunan yang rutin dilaksanakan sejak wafatnya Habib Abu Bakar bin Muhammad Assegaf pada tahun 1376 H/1956 M dan merupakan kegiatan yang digunakan sebagai pengingat 
kematian, mendapat keberkahan, silaturrahim, dan upaya dalam mengambil teladan dari para salaf terdahulu (Mahzumi 2014). Peringatan houl tersebut dilaksanakan pada setiap tanggal 16-17 Dzulhijjah di kediamannya jalan KH. Zubair Desa Pulopancikan Kabupaten Gresik. Kegiatan yang dilakukan dalam peringatan houl tersebut antara lain dibuka dengan rawhah yakni dengan mengkhatamkan kitab ihya' ulumuddin, dilanjutkan dengan makan malam bersama berupa nasi kebuli, kemudian ditutup dengan pembacaan kitab maulid diba' dan zikir,

Selain itu, terdapat kegiatan keagamaan tahlilan atau pengajian orang meninggal. Kegiatan tahlilan atau pengajian orang meninggal hampir sama dengan orang Jawa pada umumnya yang terdapat peringatan 7 hari, 40 hari atau 100 hari wafatnya orang yang meninggal. Terdapat hal unik dalam proses pemakaman orang keturunan Arab yang meninggal, dimana masyarakat keturunan Arab memiliki mudin sendiri yakni mudin Arab yang mengurusi prosesi pemakaman. Mudin khusus ini tidak sama dengan mudin desa yang mengurusi pemakaman penduduk lokal. Tempat pemakaman orang Arab yang meninggal kebanyakan di Kompleks Makam Sumur Songo.

\section{G. Kesenian}

Kesenian yang ada di Kampung Arab Desa Pulopancikan berupa kesenian sholawatan musik rebana dan gambus yang ditampilkan pada kegiatan-kegiatan tertentu. Gambus merupakan alat musik yang berasal dari Timur Tengah. Gambus terdiri dari beberapa alat musik seperti gendang, biola, dan seruling. Kesenian gambus diadakan ketika terdapat masyarakat yang melangsungkan pernikahan atau hajatan lain baik oleh dari etnis Arab maupun non Arab. Selain itu seni bangunan yang bernuansa Arab menjadi ciri khas rumah masyarakat keturunan Arab.

\section{Interaksi Sosial Masyarakat Kampung Arab dengan Penduduk Lokal Desa Pulopancikan Kabupaten Gresik}

Masyarakat dalam kehidupan sehari-hari pasti akan melakukan interaksi sosial. Begitu pula pada masyarakat keturunan Arab dan penduduk lokal di Desa Pulopancikan Kabupaten Gresik. Interaksi sosial yang dilakukan masyarakat keturunan Arab dengan penduduk lokal Desa Pulopancikan Kabupaten Gresik terdiri dari 3 jenis:

\section{A. Human Social life (Kehidupan Sosial Manusia)}

Manusia tidak terlepas dari kehidupan sosial dengan masyarakat. Kehidupan sosial manusia merupakan tindakan yang dilakukan manusia dengan manusia lain dalam kehidupannya. Begitu pula pada masyarakat keturunan Arab yang melakukan hubungan sosial dengan penduduk lokal Desa Pulopancikan Kabupaten Gresik. Masyarakat keturunan Arab melakukan interaksi sosial dengan penduduk lokal Desa Pulopancikan karena beberapa hal seperti belanja untuk kebutuhan sehari-hari di toko, acara pernikahan, tahlilan, dan juga kegiatan rutin yang ada di desa. Selama ini penduduk lokal Desa Pulopancikan sulit untuk menemui masyarakat keturunan Arab karena karena beberapa kediaman atau rumahnya tertutup, dimana bentuk rumah masyarakat keturunan Arab memiliki bangunan dinding tinggi dan memiliki pekarangan yang luas di dalam rumah. 


\section{B. Human Social Reality (Realitas Sosial Manusia)}

Realitas sosial manusia merupakan proses pemaknaan dari kehidupan manusia. Dalam kehidupannya, manusia pasti melakukan interaksi sosial yang mana interaksi tersebut mempunyai makna dalam setiap tindakannya. Hal tersebut selaras dengan pendapat dari Tamunu, dkk. (2018) yang menyatakan bahwa interaksi berfokus pada pentingnya membentuk makna bagi perilaku manusia yang berhubungan dengan komunikasi. Seperti halnya yang terjadi pada interaksi sosial masyarakat keturunan Arab dengan penduduk lokal Desa Pulopancikan Kabupaten Gresik dimana terdapat makna dalam setiap proses interaksi sosial yang terjadi. Interaksi sosial masyarakat keturunan Arab dengan penduduk lokal bersifat baik, akan tetapi untuk proses komunikasi antara masyarakat Arab dengan penduduk lokal jarang terjadi karena masyarakat keturunan Arab memiliki prinsip untuk lebih baik diam daripada tidak bisa tapi banyak berbicara. Hal tersebut sesuai dengan ajaran agama Islam bahwa manusia harus menjaga lisan dari perkataan buruk karena perkataan buruk dari lisan manusia akan berdampak pada kehidupan sosialnya (Rizkiputra, n.d.).

Bentuk kerjasama yang dilakukan antar masyarakat keturunan Arab di Kampung Arab Desa Pulopancikan yakni dalam hal kegiatan kegamaan, salah satunya yakni kegiatan rutin setiap setahun sekali houl Habib Abu-Bakar. Dalam kegiatan tersebut, antar masyarakat keturunan Arab melakukan kerja sama dalam menyiapkan acara maupun kebutuhan kegiatan seperti makanan dan juga properti kegiatan (sound, tenda, dan lain-lain). Selain itu, terdapat pula kerja sama dalam hal pembangunan rumah salah satu masyarakat keturunan Arab yang danannya berasal dari masyarakat keturunan Arab. Bentuk akomodasi yang dilakukan antar masyarakat keturunan Arab Desa Pulopancikan adalah sikap saling menghargai dan mendukung antar masyarakat keturunan Arab, dimana kelompok masyarakat keturunan Arab tersebut sangat menghindari adanya pertikaian atau konflik dalam hal apapun dan jika terjadi konflik maka akan diselesaikan sendiri melalui proses kekeluargaan. Sedangkan bentuk interaksi sosial dalam hal kerja sama yang dilakukan masyarakat keturunan Arab di Kampung Arab dengan penduduk lokal Desa Pulopancikan adalah pada bidang ekonomi yakni penduduk lokal sebagai pegawai pabrik sarung yang dimiliki oleh masyarakat keturunan Arab. Sedangkan bentuk akomodasi masyarakat keturunan Arab dengan penduduk lokal adalah dengan adanya sikap toleransi agama dan kebudayaan karena di Desa Pulopancikan merupakan desa multietnis dan multiagama.

Adanya sistem pernikahan yang patrilineal dalam kehidupan masyarakat keturunan Arab dapat menjadi hambatan dalam kehidupan masyarakat, karena dengan adanya sistem pernikahan yang mengutamakan sesama keturunan Arab, maka hal tersebut menjadi batasan dalam hubungan sosial antara masyarakat keturunan Arab dengan penduduk lokal Desa Pulopancikan. Sehingga sistem kekerabatan patrilineal tersebut menyebabkan munculnya in group feeling dimana adanya perasaan yang kuat bahwa individu terikat pada kelompok dan kebudayaan dalam suatu kelompok masyarakat (Soekanto, 2013).

\section{Individual life (Kehidupan Individu)}


Manusia merupakan makhluk sosial yang tentunya memiliki kepentingan sendiri dalam kehidupannya. Hal tersebut dapat dikatakan sebagai kehidupan individu yang dimiliki oleh manusia. Kehidupan individu masyarakat keturunan Arab memiliki sikap yang tertutup dengan kehidupan sosial, maksudnya masyarakat Arab memiliki batasan berinteraksi terhadap penduduk lokal, akan tetapi lebih dapat berhubungan dengan sesama masyarakat keturunan Arab. Selain itu, karakteristik masyarakat keturunan Arab juga dapat dilihat dari kebiasaan orang Arab yang menyukai hal yang mewah dan meriah dalam setiap acara atau kegiatan tertentu seperti pernikahan. Dalam kehidupan sehari-hari, masyarakat keturunan Arab menggunakan sarung atau pakaian jubah lakilaki dan juga kopyah. Sedangkan untuk masyarakat keturunan Arab perempuan menggunakan jubah perempuan dan juga kerudung panjang. Selain itu beberapa perempuan keturuna Arab juga menggunakan cadar apabila keluar dari rumah.

\section{KESIMPULAN}

Awal mula keberadaan Kampung Arab Desa Pulopancikan Kabupaten Gresik berasal dari datangnya bangsa Arab Hadramaut pada sekitar abad ke-12 yang melakukan kegiatan berdagang dan juga berdakwah untuk menyebarkan ajaran agama Islam. Keberadaan Kampung Arab ini tidak hanya karena adanya Syekh Malik Ibrahim saja, akan tetapi juga karena Gresik sebagai kota pelabuhan sekaligus jalur lalu lintas pelayaran yang menyebabkan banyaknya orang asing seperti pedagang dari Arab yang menetap sementara maupun selamanya. Hal tersebut menjadikan wilayah yang didatangi oleh pedagang maupun pendakwah menjadi sebuah permukiman yang disebut dengan Kampung Arab.

Masyarakat keturunan Arab di Kampung Arab Desa Pulopancikan Kabupaten Gresik mempunyai karakteristik budaya yang khas dimana masih terdapat budayabudaya Arab meskipun telah terdapat akulturasi dengan budaya Jawa. Karakteristik budaya masyarakat keturunan Arab di Kampung Arab Desa Pulopancikan Kabupaten Gresik dapat dilihat dari bahasa, sistem pengetahuan, organisasi sosial, sistem mata pencaharian hidup, sistem peralatan dan teknologi, Religi, dan kesenian.

Interaksi sosial masyarakat keturunan Arab dengan penduduk lokal Desa Pulopancikan Kabupaten Gresik dimana terdapat makna dalam setiap proses interaksi sosial yang terjadi. Interaksi sosial masyarakat keturunan Arab dengan penduduk lokal bersifat baik, akan tetapi untuk proses komunikasi antara masyarakat Arab dengan penduduk lokal jarang terjadi karena masyarakat keturunan Arab memiliki prinsip untuk lebih baik diam daripada tidak bisa tapi banyak berbicara.

\section{DAFTAR RUJUKAN}

\section{Buku dan Jurnal}

Ajami, Hassan. 2016. "Arabic Language, Culture, and Communication." International Journal of Linguistics and Communication 4 (1): 120-23. 
Bisyarda, Muhammad Iqbal. 2016. "BUDAYA KERATON PADA BABAD TANAH JAWI DALAM PERSPEKTIF PEDAGOGI KRITIS." Sejarah Dan Budaya : Jurnal Sejarah, Budaya, Dan Pengajarannya. https://doi.org/10.17977/um020v10i22016p174.

Burhan, Bungin. 2006. "Sosiologi Komunikasi: Teori, Paradigma, Dan Diskursus Teknologi Komunikasi Di Masyarakat." Jakarta: KENCANA Prenada Media Group. https://doi.org/10.1186/1758-5996-1-20.

Handinoto, Handinoto. 1999. "LINGKUNGAN" PECINAN" DALAM TATA RUANG KOTA DI JAWA PADA MASA KOLONIAL." DIMENSI Uournal of Architecture and Built Environment) 27 (1).

Hilmiyyah, Dewi Roihantul. 2019. "Pelabuhan Gresik Sebagai Proses Perdagangan Islamisasi Abad XV-XVI M." Journal of Chemical Information and Modeling. https://doi.org/10.1017/CB09781107415324.004.

Koentjaraningrat. 2009. Pengantar Ilmu Antopologi. Jakarta: Rineka Cipta.

Mahzumi, Fikri. 2014. "Telaah Sosio-Antropologis Praktik Tarekat 'Alawiyah Di Gresik." Marâji : Jurnal Ilmu Keislaman.

Poespasari, Ellyne Dwi, and M H SH. 2016. "Perkembangan Hukum Waris Adat Di Indonesia." Zifatama.

Pusat, Tim, Studi Timur, Tengah Universitas, Padjadjaran Apa, Dimana Timur Tengah, Timur Tengah, Timur Tengah, et al. n.d. "Sekilas Mengenai Studi Timur Tengah" 20.

Rizkiputra, Dikalustian. n.d. "Bahaya Lisan Dan Pencegahannya Dalam Al-Qur'an (Sebuah Kajian Tematik)."

Saidah, Anis. 2015. "Perkembangan Komunitas Arab Di Kota Gresik Tahun 1830-1930." SKRIPSI Jurusan Sejarah-Fakultas Ilmu Sosial UM.

Shelvira. 2019. "Manajemen Konflik Orang Tua Dan Anak Perempuan Dalam Perjodohan Pada Keluarga Keturunan Arab Di Gresik." Universitas Airlangga. http://repository.unair.ac.id/id/eprint/84141.

Suhandjati, Sri. 2018. "KEPEMIMPINAN LAKI-LAKI DALAM KELUARGA: Implementasinya Pada Masyarakat Jawa." Jurnal THEOLOGIA 28 (2): 329-50.

Sukmadinata, Nana Syaodih. 2016. Metode Penelitian Pendidikan. Bandung: Remaja Rosdakarya.

Tamunu, Vico Risky, Fonny J Waani, and Selvie M Tumengkol. 2018. "ANALISIS INTERAKSIONISME SIMBOLIK TERHADAP PENYIMPANGAN PERILAKU SISWA (Kajian Sosiologi Pendidikan Terhadap Pelanggaran Tata Tertib Siswa Di SMA Negeri 9 Manado)." HOLISTIK, Journal Of Social and Culture.

Wiretno. 2018. "Ini Kampung Arab Tertua Di Gresik." Surya, April 7, 2018. https://surabaya.tribunnews.com/2018/04/07/ini-kampung-arab-tertua-digresik?page $=2$.

Yunita, Fitra. 2017. “Pekojan, Saksi Bisu Kedatangan Bangsa Arab Di Nusantara.” Liputan6, 2017. https://www.liputan6.com/news/read/2881372/pekojan-saksi-bisukedatangan-bangsa-arab-di-nusantara.

Zainuddin, Oemar. 2010. Kota Gresik, 1896-1916: Sejarah Sosial Budaya Dan Ekonomi. Ruas. 